\title{
Institutional Equivalence: How Industry and Community Peers Influence Corporate Philanthropy
}

\author{
Christopher Marquis \\ Cornell University, Ithaca, New York 14853, cmarquis@cornell.edu \\ András Tilcsik \\ University of Toronto, Toronto, Ontario M5S 3E6, Canada, andras.tilcsik@ rotman.utoronto.ca
}

\begin{abstract}
$\mathrm{T}_{\mathrm{i}}^{\mathrm{h}}$ his paper explores how organizations respond to simultaneous institutional influences from two distinct sources: the 1 industry in which they operate and the local geographic community in which they are headquartered. We theorize that the existence of institutional equivalents - other organizations at the same intersection of different fields, such as the same industry and the same community_provides a clear and well defined reference category for firms and thus shapes which subset of peers the focal organization imitates most closely. We develop hypotheses about how the presence or absence of institutional equivalents affects organizations' responses to behavioral cues from different peer groups, how these effects vary when peers in different fields exhibit inconsistent behaviors, and how organizational characteristics, such as size and performance, strengthen or weaken the influence of institutional equivalents. We test our propositions through a longitudinal analysis of philanthropic contributions by Fortune 1000 firms from 1980 to 2006. Our framework illuminates how simultaneous presence in multiple fields affects organizations and introduces to institutional theory the concept of institutional equivalence, which we argue is a critical factor in determining how organizations respond to multiple institutional cues.
\end{abstract}

Keywords: institutional theory; institutional fields; community; philanthropy; corporate social responsibility History: Published online in Articles in Advance October 3, 2016.

\section{Introduction}

A classic insight of institutional theory is that organizations look to their peers for cues to appropriate behavior (DiMaggio and Powell 1983). Yet recent studies have shown that organizations are often embedded in more than just one institutional field, settings where they "partake of a common meaning system and...interact more frequently and fatefully with one another than with actors outside the field" (Scott 2001, p. 84). Thus, organizations often receive behavioral cues from more than one set of peers (Greenwood et al. 2011) and experience "multiple institutional prescriptions projected by different audiences" (Greenwood and Meyer 2008, p. 263). The juxtaposition of these two insights raises a fundamental question: When organizations are embedded in multiple institutional fields, which set of peers do they imitate, and what factors shape their response to such situations?

How do organizations respond, for example, when they are simultaneously exposed to cues from peers in their industry (DiMaggio and Powell 1983, Palmer et al. 1993) and cues from peers in their geographic community (Freeman and Audia 2006, Lounsbury 2007, Marquis and Battilana 2009)? Although simultaneous embeddedness in industries and geographic communities is a ubiquitous and enduring situation, limited research has examined its consequences. While fields may maintain stability in the face of multiple institutional influences (Dunn and
Jones 2010, Reay and Hinings 2009), the implications of permanent embeddedness in more than one field have remained largely unexamined. Much prior work on multiple institutional influences has focused instead on temporary conflicts between different behavioral cues, often exploring processes of institutional transitions within a single field (e.g., Thornton and Ocasio 1999, Scott et al. 2000). Related research suggests that organizations in such situations might, for example, ignore one or both peer groups (Oliver 1991), relate independently to each of them (Davis and Greve 1997), balance inconsistent influences through compromise (Rowan 1982), or combine different cues into a hybrid organization (Battilana and Dorado 2010, Pache and Santos 2013). To date, however, most scholars have only speculated about the contingencies that shape how organizations navigate their enduring presence in multiple fields (Kraatz and Block 2008, Pache and Santos 2010, Greenwood et al. 2011).

To advance scholarship in this area, we propose that a critical factor shaping the behavior of an organization embedded in multiple fields is whether it occupies the intersection of the different fields alone or shares it with institutional equivalents, that is, other organizations that exist at the same intersection (e.g., other firms embedded in both the same industry and the same geographic community). We theorize that the presence (versus absence) of institutional equivalents shapes which subset of peers 
the focal organization imitates most closely and how it responds when its peers in different fields exhibit inconsistent behaviors. When institutional equivalents exist, they serve as an obvious reference category of peers that the focal organization is likely to imitate especially closely, while paying relatively less attention to peers with which it shares only a single field. Furthermore, when the contrast between the behavior of peers in the different fields is greater, firms experience more uncertainty and so will be even more likely to follow their institutional equivalents. In contrast, organizations without institutional equivalents-those in an institutionally unique position-will simultaneously attend to the different behavioral cues from distinct fields. Finally, we further unpack the effect of institutional equivalents by considering how their influence varies depending on two basic characteristics of the focal organization: size and performance.

We elaborate and test these arguments in the context of corporate philanthropy in the United States between 1980 and 2006. This setting offers two major advantages. First, unlike practices that are specific to a particular set of industries, corporate philanthropy is an activity that any firm might engage in, which allows us to make meaningful comparisons across a wide range of industries. Second, this is a setting in which the simultaneous influence of industry and community institutional cues is clear and readily analyzable. While research has indicated that institutional influences from a firm's focal industry are key to understanding philanthropic actions (Wolch 1995, Brammer and Millington 2005), the literature also highlights the effect of local environments on corporate philanthropy (Marquis et al. 2007, Tilcsik and Marquis 2013). Thus, when making decisions about philanthropy, "firms not only benchmark against other firms within their industry, but also against other [firms], particularly those within their local geographic context" (Bertels and Peloza 2008, pp. 60-61). Little is known, however, about how firms respond to these two distinct institutional influences, and which set of peers - and under what conditions-has a greater influence on their philanthropic giving.

By developing a more nuanced theory of how simultaneous presence in multiple fields affects organizations, we introduce the concept of institutional equivalence and elaborate how and why it is key to understanding the common situation where firms are embedded in multiple fields. Our theory and findings suggest that, without considering institutional equivalents, research on mimetic isomorphism that only considers the effects of single fields may be incomplete and potentially misspecified. Furthermore, as we elaborate in the discussion, while our focus is on firm position vis-à-vis two distinct fields, our arguments also have more general implications for understanding peer imitation processes, particularly as firms face increasingly multifaceted institutional environments.

\section{Institutional Fields and Corporate Philanthropy}

It is well established that firms are more likely to follow practices that peers in their field have adopted (Palmer et al. 1993, Rao et al. 2001). In particular, prior research has shown that industry (Scott 2001, Wooten and Hoffman 2008, Raffaelli et al. 2013) and community (Warren 1967, Marquis et al. 2013) peers are the most crucial set of referents for understanding institutional influences on firms. For instance, a number of empirical studies have measured firms' fields as common industry membership and found that such fields affect the adoption of important organizational features, such as structural form (Fligstein 1985), business strategy (Deephouse 1996), organizational name (Glynn and Abzug 2002), and social responsibility practices (Raffaelli and Glynn 2014). Furthermore, research has also shown that even in today's global environment, firms with the same headquarters city remain a crucial peer group for firms (Marquis and Battilana 2009). Community embeddedness, for example, affects corporate governance (Davis and Greve 1997, Kono et al. 1998), strategy (Lounsbury 2007), and the establishment of new organizations (Almandoz 2012, Audia et al. 2006).

Less understood are the implications of organizations' enduring embeddedness in multiple different fields (Davis 2010). While theorists have called for understanding multidimensional institutional influences on organizations (Friedland and Alford 1991, Thornton et al. 2012), these studies have mainly looked within a single field and examined the mechanisms that allow for fields with multiple institutions to maintain stability (Dunn and Jones 2010, Purdy and Gray 2009, Reay and Hinings 2009). For example, the institutions of care and science are typically in conflict but can coexist in the field of medical education because each is supported by distinct groups and interests (Dunn and Jones 2010). In contrast, simultaneous behavioral cues from different fields are ongoing and persistent, so organizations embedded in more than one field continuously face uncertainty about which set of peers to imitate, and the mechanisms of how they address this situation are yet to be uncovered.

The case of corporate philanthropy illustrates this ongoing uncertainty due to different behavioral cues from distinct fields. Research has suggested that firms imitate both industry and community peers when setting the level of their philanthropic contributions. For example, qualitative and survey-based studies have found that most firms gather information about industry peers' charitable activities (Siegfried et al. 1983, Bertels and Peloza 2008), and that peer company comparisons are an important factor when companies make decisions about their philanthropic budgets (Useem and Kutner 1986) and other corporate social practices (Raffaelli and Glynn 2014). Likewise, research shows that the charitable giving of locally headquartered corporations is embedded in community-based 
social relationships and that local expectations significantly influence firms' social engagement (Bertels and Peloza 2008, Galaskiewicz 1997, Marquis et al. 2007). For example, in the "urban grants economy" of the Twin Cities, Galaskiewicz (1997) found that locally headquartered companies exerted significant influence on one another to support local nonprofits. As executives interviewed by Bertels and Peloza (2008, pp. 62-63) put it, "We take our cues from the other big companies in town" and "when we look around at how we can get involved, we do so on a city-wide basis. We look to see who is setting the standard and set that as our goal." These different peer groups, however, sometimes send different signals about the appropriate level of giving, creating uncertainty about whom to imitate.

While research has shown that strategic considerations-particularly about the firm's reputation and legitimacy with customers and various other stakeholdersinfluence philanthropy (see McWilliams and Siegel 2001), there is no simple calculus for determining the "right" level of corporate giving, and there is often a great deal of uncertainty about the appropriate amount of philanthropy (Bertels and Peloza 2008). The existence of this uncertainty likely accentuates the common fault line within firms between financially oriented and socially orientated employees (Almandoz 2014, Battilana and Dorado 2010, Pache and Santos 2013). When it is unclear which benchmark or standard should be followed, "each manager is left to his or her own devices to determine how much... [philanthropy] is "enough" (Bertels and Peloza 2008, p. 64), and this may be a source of contention within firms. Prior research has suggested that differences in philanthropic motivations of actors within an organization can generate internal conflict and affect firms' philanthropic decision making (Hemingway and Maclagan 2004, Marquis and Lee 2013). As a result of this uncertainty and how it affects internal firm dynamics and decision making, the degree of corporate charitable contributions varies greatly even among equally large and profitable firms (Galaskiewicz 1997, Useem 1988, Tilcsik and Marquis 2013).

\section{Institutional Equivalence}

The theory we develop focuses on how and why institutional equivalents - organizations that are embedded in the same set of fields - are the primary reference group for a firm when making decisions about philanthropic giving. While prior research has tended to focus on only one set of peers-for example, those in either the firm's industry or its community-we argue that looking at the overlap of multiple institutional fields may help better differentiate which organizations are actually seen as the relevant reference group for a firm. Institutional equivalents serve this exemplar role for other firms, not because of their specific organizational characteristics, but because, given the similarity of their institutional position with the focal organization, they are exposed to a similar set of institutional cues. As Greve (2005, p. 1032), noted "even when no social tie is present, [organizational] actors may watch and imitate each other because they view the other ....as being in a similar environment." We argue that this kind of imitation based on a shared or similar environment is likely to be particularly important with regard to institutional equivalents, as these are peers with which a firm shares not one but multiple institutional environments. ${ }^{1}$

In our context, two firms are institutional equivalents if they operate in the same industry and are headquartered in the same geographic community-that is, if they are industry peers that are also local geographic peers. A long-standing line of research has examined specific local industrial clusters (Romanelli and Khessina 2005) as distinct institutional environments that may affect firm behavior. For example, there is evidence that as the hightechnology industry developed, high-tech firms in Boston were more influenced by peers that were both in the same community and in the same industry than by high-tech firms headquartered in other locations (Saxenian 1994). And similar processes have been shown for automakers in Detroit (Klepper 2007), tire makers in Akron (Sull 1999), and biotechnology firms in Boston (Owen-Smith and Powell 2004). While these case studies of local industrial clusters are suggestive of the importance of institutional equivalents, this research has not developed the idea that having similar peers at the industry-community overlap is a generalizable phenomenon-one that has relevance for all firms, not just those in industrial districts. It also has not considered the possibility that, as we hypothesize below, the existence of institutional equivalents affects the extent to which firms imitate their other industry or community peers.

We argue that the presence or absence of institutional equivalents powerfully shapes an organization's response to uncertainty that results from potentially inconsistent behavioral cues from different sets of peers. As noted, when institutional equivalents exist, they will serve as an obvious reference category of imitable peers, implying that the focal organization will pay relatively little attention to other industry peers (i.e., those headquartered in different communities) and other community peers (i.e., those that operate in a different industry). Instead, organizations in such a position will likely be particularly influenced by peers in a third reference category: their institutional equivalents, which provide a clear reference category, thereby reducing uncertainty about where to look for appropriate behaviors.

This prediction is consistent with research on cognitive categorization, which has shown that similarity on multiple dimensions, rather than just a single dimension, is a critical variable influencing whether managers perceive another organization as part of their firm's peer group (e.g., Lant and Baum 1995). The idea that institutional 
Figure 1 Illustrative Example of Institutional Equivalence: Bank of America's Peers in Its Industry (Commercial Banks) and Geographic Community (Charlotte) in 2006

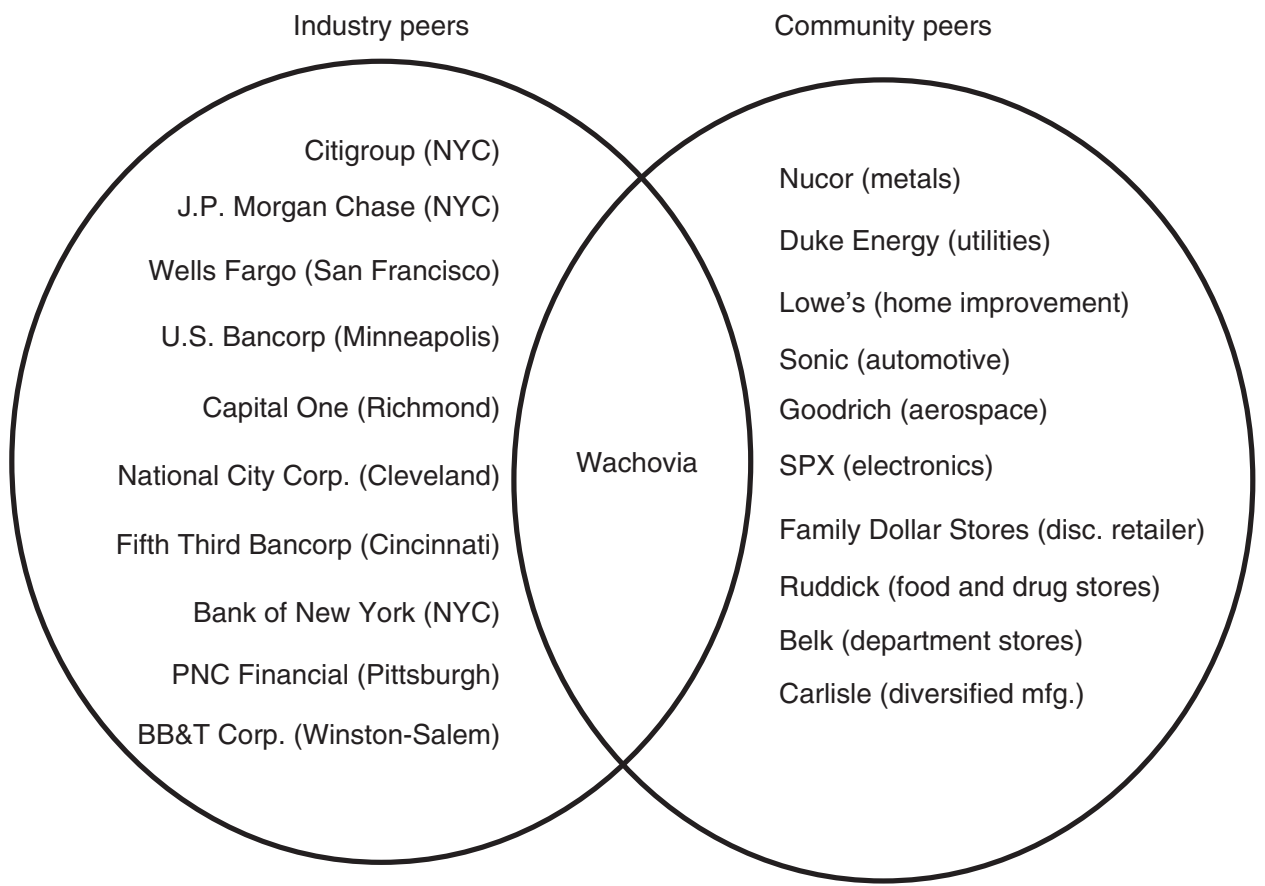

Note. The 10 largest industry peers and the 10 largest community peers (by revenue) are shown.

equivalents constitute an especially influential reference group also dovetails with the general sociological observation that social actors tend to interact with, and are most likely to be influenced by, other actors who are like themselves along multiple dimensions (see Moody 2001, Block and Grund 2014).

Consider, for example, the situation of Bank of America in 2006, the last year in our empirical observation period. As Figure 1 shows, Bank of America had numerous peers in the banking industry located in other geographic communities. And it had several community peers in the Charlotte, North Carolina, metropolitan area that operated in other industries. But, at the time, it also had a clear institutional equivalent-another major bank headquartered in Charlotte: Wachovia. Our theory suggests that, in that period, Bank of America was most likely to take cues from Wachovia, rather than its other industry or community peers. Indeed, press accounts indicate a special relationship between the two firms, as the combination of a shared industry and a shared community seems to have created both motivation and opportunity to "monitor each other obsessively" (Hankins 2007). Many of the two firms' executives, for example, lived "next door to each other" and, as a former Bank of America executive put it, attended the "same clubs, same parties, same everything" (Fitzpatrick 2006). And, because of their position in the same industry and community, there was a palpable sense of rivalry in both business and philanthropic affairs, leading both firms to closely watch-and try to match-each other's moves in activities as diverse as support and sponsorship of sports teams and customer service levels (Hankins 2007). As a result, for example, both firms would "sponsor nearly every civic event in town" (Fitzpatrick 2006), had directors on the boards of the very same philanthropic organizations, and toggled with each other "between being number one and two [in donations] for United Way for years" (Hankins 2007).

Accordingly, based on our theorizing and examples from prior research, we hypothesize that a firm's institutional equivalents constitute an important and unique reference category, which is likely to overshadow the influence of industry-only and community-only peers.

HyPOTHESIS 1 (H1). The philanthropic contributions of institutional equivalents have a greater influence on a firm's contributions than do the contributions of its other industry or community peers.

Not all firms, however, have institutional equivalents; some occupy an industry-community intersection alone. Take, for example, U.S. Bancorp, another major bank, in 2006. As Figure 2 shows, while U.S. Bancorp had a number of industry peers, all of these were headquartered in other cities, such as Charlotte, New York, and San Francisco. And, though U.S. Bancorp also had numerous community peers, they were all operating in different industries, from airlines to wholesalers. Thus, as the only major bank headquartered in the Twin Cities, U.S. Bancorp was in an institutionally unique position at the overlap of an industry and a local community. Unlike 
Figure 2 Illustrative Example of the Absence of Institutional Equivalents: U.S. Bancorp's Peers in Its Industry (Commercial Banks) and Geographic Community (Twin Cities) in 2006

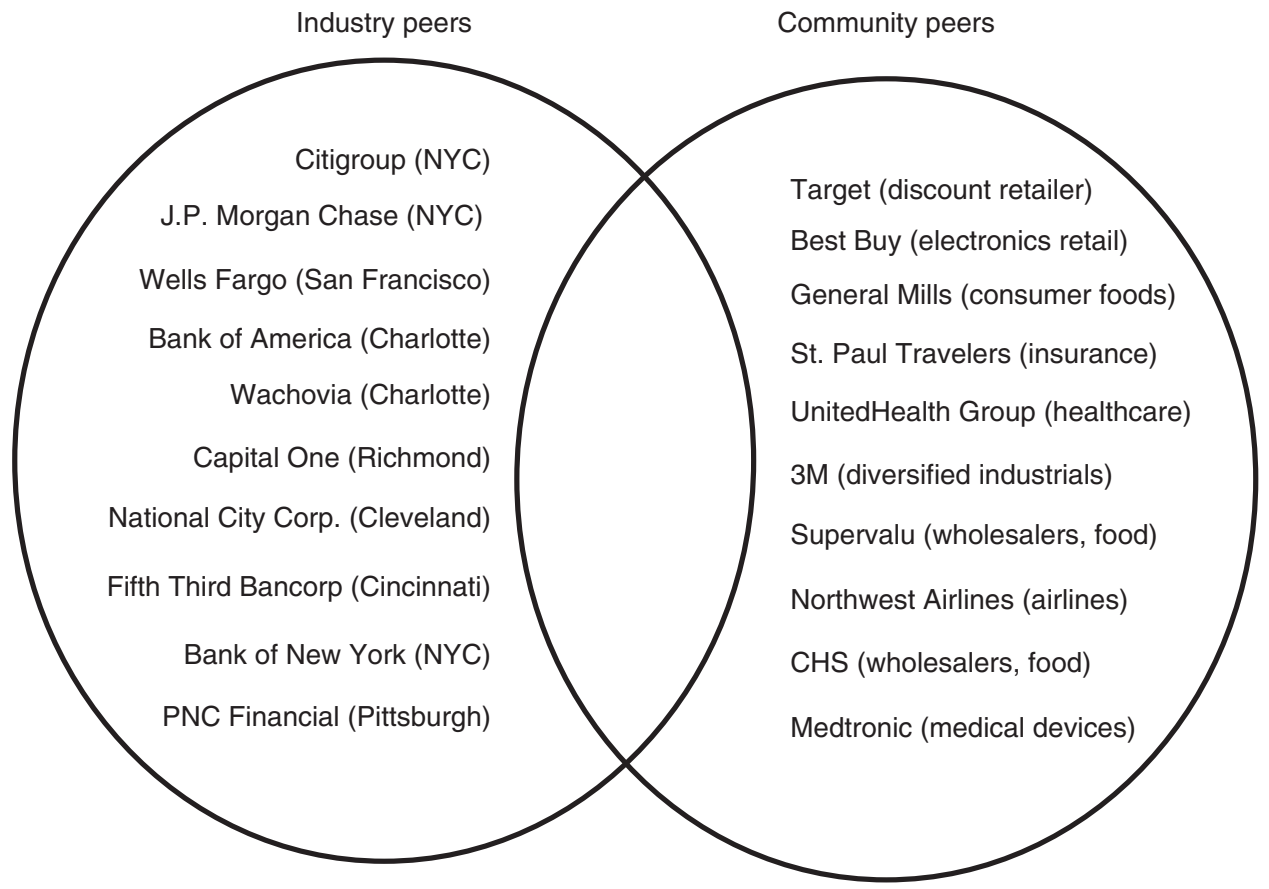

Note. The 10 largest industry peers and the 10 largest community peers (by revenue) are shown.

prior research that has tended to look at either industry peers (e.g., DiMaggio and Powell 1983) or community peers (e.g., Marquis and Battilana 2009), for such firms, we expect that the standard peer effects previously shown in the literature will simultaneously shape philanthropic giving; that is, as described above, firms without institutional equivalents are likely to follow both their industry peers and their community peers-a fundamentally different imitation pattern than what we expect for firms with institutional equivalents, which have a single obvious reference category to follow.

HyPOTHESIS $2(\mathrm{H} 2)$. If a firm has no institutional equivalents, the philanthropic contributions of both (a) its industry peers and (b) its local peers will be positively related to its own contributions.

\section{Institutional Equivalence and Inconsistent Behaviors by Different Peer Groups}

While research has suggested that both industry and community peers may be important sources of institutional influence on a firm's philanthropic behavior, less research has examined situations where an organization's peers in different fields exhibit divergent behaviors. For example, how do firms deal with situations when peers in one field are setting their philanthropic contributions at a high level while those in another field are keeping the level of their donations low? In such situations, the focal firm experiences inconsistent behavioral cues from different fields and might face the challenge of accommodating multiple peer influences at the same time.
While enduring embeddedness in multiple fields does not necessarily imply that the cues arising from different fields are always and necessarily in conflict (Besharov and Smith 2014), prior research and historical evidence suggest that industry and community peers frequently provide inconsistent behavioral cues regarding philanthropic giving. This is, in part, because there is little overall consensus about the appropriate level of corporate philanthropy. Indeed, some have even questioned the appropriateness of any form of corporate giving. In an influential essay in the New York Times Magazine, for example, Milton Friedman (1970) forcefully argued that corporations should eschew charitable donations. According to Friedman, and more recent commentators building on his arguments, philanthropy is a misdirection of shareholder resources, and executives who have an interest in philanthropy should make individual donations (see Margolis and Walsh 2003). In contrast, others believe that philanthropy generates both social and business benefits and is a part of the corporate "social contract" (Porter and Kramer 2002, Coady 2008).

In the absence of a clear overall consensus about the appropriateness of philanthropy, there is significant variation in this practice across communities and industries. At the community level, for example, while Galaskiewicz's $(1985,1997)$ analyses show that philanthropic generosity is highly legitimate and expected from all companies in the Twin Cities, the typical amount of corporate contributions is substantially lower in many other cities (Marquis et al. 2007). For example, in stark 
Figure 3 Variation in the Average Level of Corporate Philanthropy in Select Industries and Communities in 1994

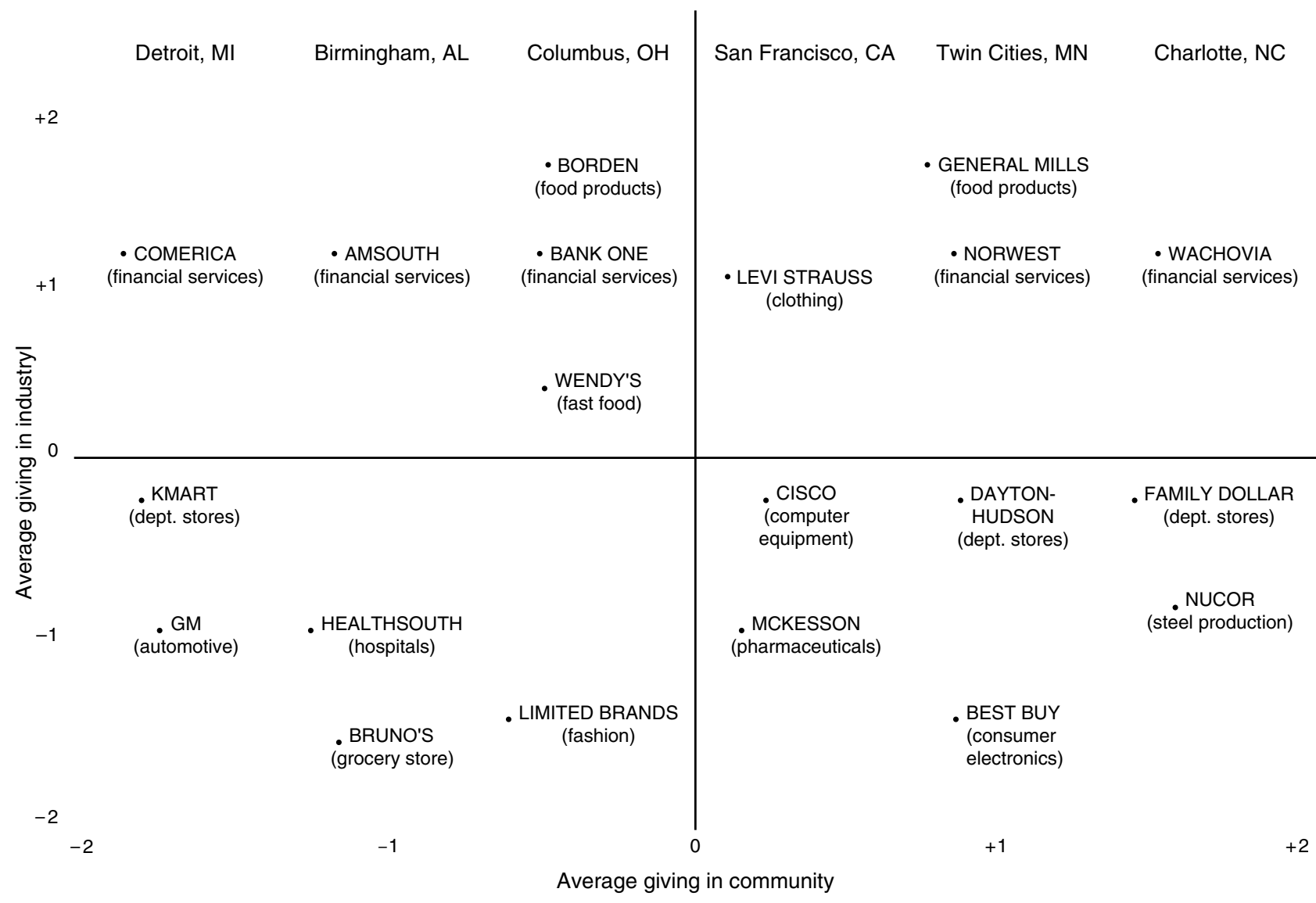

Notes. This illustrative graph depicts the location of select firms in a space determined by the average philanthropic giving per sales in their community and in their industry (z-scores) in 1994 (the midpoint of our observation window). Thus, for example, firms in the upper-left quadrant were in a relatively generous industry while being headquartered in a community with a relatively low standard level of corporate giving. The graph provides no information about the level of giving by any of these individual firms; rather, it indicates the standard level of giving in their focal industries and headquarters communities.

contrast to Minneapolis, many Silicon Valley companies in the late 1990s were known as "cyber stingy" espousing an ideology of self-reliance that proscribed charitable donations (Elkind 2016). Similar variation in the legitimacy of philanthropy occurs across industries as well (Brammer and Millington 2005). For example, while generous philanthropic giving has significant legitimacy in commercial banking for historical and legal reasons (Marquis et al. 2007), keeping charitable donations at a low level is common in some other industries, for example, those without direct consumer contact (Burt 1983).

To illustrate the inconsistent institutional cues that firms might face with regard to corporate philanthropy, Figure 3 highlights variation in the average level of philanthropic giving in select industries and communities in 1994, the midpoint of our observation window. Looking from left to right, it is clear that there is considerable variation in the average level of giving across these cities, from Detroit and Birmingham as the least generous corporate communities to Minneapolis and Charlotte as the most generous ones. Similarly, looking from top to bottom, there is significant variation across industries, from the most generous food product and banking firms to retailers and manufacturers. As a result of these variations, many firms are simultaneously embedded in a focal industry and a headquarters community that may differ substantially from each other in the standard level of corporate giving, thus experiencing high-low or low-high combinations of average industry and community giving. The question, then, is how organizations respond to these frequently divergent institutional cues.

Increased uncertainty is well known to play a critical role in how and why organizations in a field imitate one another (Cyert and March 1963, Haunschild and Miner 1997, Henisz and Delios 2001), and uncertainty created by inconsistencies in institutional cues can put a strain on organizations as they aim to determine the appropriate response (Seo and Creed 2002). Similarly, Schneiberg and Clemens (2006) suggest that field heterogeneity decreases institutional effects. We argue that when there are inconsistent behavioral cues, the different peer groups will pull the organization in different directions and so increase 
the uncertainty about how much giving is appropriate. Research on social proof, in turn, suggests that when there is greater uncertainty, firms rely especially heavily on their most salient and legitimate reference group (Rao et al. 2001). As we described above, when institutional equivalents exist, they constitute a uniquely relevant set of peers for imitation, and so when there is uncertainty due to inconsistent signals in the industry and the community, we predict that firms will be even more likely to imitate their institutional equivalents.

Hyротнеsis $3(\mathrm{H} 3)$. The greater the difference between the philanthropic contribution levels of industry peers and community peers, the greater the influence of institutional equivalents on a firm's contributions.

\section{Institutional Equivalence and Organizational Characteristics}

Institutional equivalents do not affect all organizations equally; the strength of their influence is likely to depend on the characteristics of the focal organization. As Martin (2003) emphasized, actors have different attributes that make them more or less susceptible to the effects of different fields, and the influence of the environment is a function of both the environment and the characteristics of the actors themselves. Likewise, institutional scholars have recently called for research that examines "organizational filters," or how the "characteristics of the organization... make it particularly sensitive to certain [institutional cues] ... and less so to others" (Greenwood et al. 2011, p. 319); that is, how do organizational characteristics affect the extent to which firms rely on cues from their peers?

We examine two fundamental organizational characteristics that are likely to filter the influence of institutional equivalents: the focal organization's size and performance. While these characteristics are well studied in the organizational literature, less considered is the extent to which they affect how closely an organization attends to the behavior of its peers. Based on prior institutional research, we argue that because large firms are more visible and so subject to greater scrutiny, they are more likely than small firms to closely imitate their institutional equivalents; conversely, higher-performing firms have less motivation to learn from others and less of a need to justify their decisions and so might be less likely to follow their institutional equivalents closely.

Organizational Size. Considerable research suggests that more visible organizations-frequently conceptualized as larger organizations - are especially susceptible to institutional influences (Greenwood et al. 2011). In particular, while being large sometimes insulates organizations from institutional effects (Greenwood and Suddaby 2006), in many cases it actually intensifies them because it provides visibility and attracts greater attention from institutional constituents and the media (King 2008,
Greenwood et al. 2011). In the context of corporate philanthropy, we believe that this latter process is more likely. As prior work has shown, large firms receive more scrutiny on their levels of giving (Brammer and Millington 2006), are more likely to be targeted by nonprofits for contributions (Galaskiewicz 1985), and are more visible to the media and the general public (McDonnell and King 2013). Thus, in the domain of corporate philanthropy, large firms are often "visible exemplars" (Greenwood et al. 2011) and as such are more responsive to institutional influences than are smaller organizations. As a result, institutional cues from multiple fields will likely pose a greater challenge for large, highly visible firms, making them especially likely to look to their institutional equivalents - their clearest and most obvious reference group - for the legitimate response.

HyротHESIS $4(\mathrm{H} 4)$. The larger the firm, the greater the influence of institutional equivalents on its philanthropic contributions.

Organizational Performance. Conversely, it is well established in the prior literature that organizations with lower performance are more likely to imitate other firms, presumably because underperforming firms have both greater motivation to learn from others (Westphal and Zajac 1994, Greve 1998) and a greater need to justify their behaviors (see Deephouse 1996). Inspired by successful examples, underperforming firms often attempt to imitate the practices of other organizations (see Strang and Macy 2001).

Since institutional equivalents serve as a clear reference group for firms, these arguments suggest that their behavior is especially likely to be followed by the lowperforming firms that are in search of the most appropriate level of philanthropic contribution. High-performing firms, in contrast, are less likely to have the same set of uncertainties and so might pay attention to the cues from others when determining their philanthropic behaviors. Thus, while the literature has suggested that higher performing firms are likely to donate more (Waddock and Graves 1997), we argue that high performance also leads firms to be less likely to imitate the donation behaviors of their relevant peers.

НyротнеSIS 5 (H5). The higher the financial performance of a firm, the weaker the influence of institutional equivalents on its philanthropic contributions.

\section{Data and Method}

\section{Sample and Dependent Variable}

To test our hypotheses, we studied the philanthropic contributions of Fortune 1000 corporations in the United States between 1980 and 2006, a period for which reliable time-series data on the relevant measures were available. Given that the largest several hundred firms are responsible for the vast majority of total corporate giving in 
the United States (Coady 2008), this sample captures the most critical segment of U.S. corporate philanthropy. We collected data on philanthropic contributions from the National Directory of Corporate Giving (Foundation Center 1981-2007) for the years 1981 to 2007. These data are available in even-numbered years. For each firm-year, we recorded our dependent variable, corporate philanthropic contributions $(C P C)$, as the total amount of grants given to charity either through a foundation or directly by the corporation. We log-transformed $(+1)$ this variable to correct for skewed values.

Because our regression models used lagged independent variables, the first year of usable observations for the dependent variable (i.e., the focal firm's giving) was 1982. Historical data on important financial control variables (such as annual sales or return on assets (ROA)) were occasionally unavailable, especially for firms that were not publicly traded at the time. ${ }^{2}$ To confirm that the missing data on the control variables did not affect the conclusions of our hypotheses tests, we also estimated alternative models without the controls (and hence without the missing observations) and found that the results of our hypothesis tests did not substantively change relative to our main models.

\section{Independent Variables}

In line with the causal sequence implied by our framework, we lagged all independent and control variables by one year, with the exception of industry and community peers' CPC, which were lagged by two years because CPC data were only available in even years. We defined industry peers as Fortune 1000 firms in the same twodigit Standard Industrial Classification (SIC) code as the focal firm. This definition is consistent with the standard practice of defining "two businesses as unrelated if they operate in different two-digit SIC codes" (Gertner et al. 2002, p. 2501; see Beckman and Haunschild 2002). ${ }^{3}$ Data on the average CPC of industry peers in a given year came from the National Directories of Corporate Giving (log-transformed; +1).

We defined community peers as Fortune 1000 firms headquartered in the same core-based statistical area (CBSA) as the focal firm. A CBSA is "a core area containing a large population nucleus, together with adjacent communities having a high degree of economic and social integration with that core" (U.S. Census Bureau 2010). Using this definition, we calculated the average $C P C$ of community peers for each year (log-transformed; +1$)$. Given the above definitions of peer groups, we conceptualized a firm's institutional equivalents as its community peers that were also simultaneously its industry peers.

To test $\mathrm{H} 3$, we created the variable industry-community difference, defined as the absolute value of the difference between industry peers' giving and community peers' giving. Conceptually, this variable captures the degree of dissimilarity between industry and community peers' levels of philanthropy. Finally, following prior research, we measured firm size as sales revenue (e.g., Marquis 2003) and financial performance as return on assets (ROA) (e.g., Ocasio 1999). We obtained these variables from Compustat. To ease the interpretation of the regression results involving interaction terms, we standardized our industry-community difference, sales, and ROA variables.

\section{Control Variables}

To carefully control for unobserved factors, all analyses included firm fixed effects, which controlled for all timeinvariant characteristics of organizations and the environment in which they existed during our time frame. Thus, our approach effectively held constant all relevant differences that were stable during the observation period. In addition, our models included year fixed effects, which controlled for all shocks, trends, and events that had similar effects across firms, such as macroeconomic changes, federal policy shifts, and general trends in philanthropy.

Moreover, we controlled for several time-variant factors that have been shown previously to affect corporate philanthropy. In addition to sales and ROA, we controlled for firm age, which we measured in logged years to avoid collinearity problems when including year fixed effects. We also controlled for the size of each relevant peer group, defining local corporate density as the number of Fortune 1000 firms headquartered in the focal firm's community, and operationalizing industry density as the number of Fortune 1000 firms in the same two-digit SIC code as the focal firm in a given year. Furthermore, we controlled for industry ROA (i.e., the average ROA of industry peers) and real per capita income at the community level (community income) - indicators of the economic situation of the two fields. These data were from Compustat and the U.S. Bureau of Economic Analysis.

\section{Statistical Approach}

We organized our data in a pooled cross-sectional timeseries format. To account for multiple observations per firm and to control for all (observed and unobserved) time-invariant differences between firms, we used fixedeffects models. Thus, our models controlled for all (even unobserved) firm characteristics that were stable during our observation period. Moreover, this approach allowed us to eliminate any confounding due to stable factors that affect both the CPC of the focal firm and the CPC of its peers. For example, because the level of corporate giving might have a stable tendency to be higher in consumeroriented industries than in business-to-business industries (Lev et al. 2010), industry type could be a possible confound, affecting both the focal firm's giving (i.e., the dependent variable) and its industry peers' giving (i.e., an independent variable). In a fixed-effects model, however, all such stable factors (from industry type to the enduring political or religious orientation of a headquarters location) are controlled for. 
Table 1 Descriptive Statistics and Correlations

A. Firms with institutional equivalents

\begin{tabular}{|c|c|c|c|c|c|c|c|c|c|c|c|c|}
\hline Variable & Mean & SD & 1 & 2 & 3 & 4 & 5 & 6 & 7 & 8 & 9 & 10 \\
\hline 1. Corporate philanthropic contributions & 1.73 & 7.41 & & & & & & & & & & \\
\hline 2. $C P C$ of institutional equivalents & 1.49 & 4.34 & 0.17 & & & & & & & & & \\
\hline 3. $C P C$ of industry peers & 1.49 & 2.32 & 0.09 & 0.13 & & & & & & & & \\
\hline 4. CPC of local peers & 1.49 & 2.51 & 0.11 & 0.24 & 0.11 & & & & & & & \\
\hline 5. Age & 18.1 & 12.8 & 0.13 & 0.12 & 0.13 & 0.13 & & & & & & \\
\hline 6. Sales & 5,536 & 13,222 & 0.49 & 0.15 & 0.09 & 0.17 & 0.20 & & & & & \\
\hline 7. $R O A$ & 0.05 & 0.05 & 0.00 & 0.03 & -0.01 & -0.01 & 0.01 & 0.00 & & & & \\
\hline 8. Industry ROA & 0.05 & 0.03 & -0.03 & 0.02 & -0.04 & -0.05 & 0.06 & -0.03 & 0.31 & & & \\
\hline 9. Community income & 34.1 & 8.1 & 0.14 & 0.12 & 0.20 & 0.40 & 0.16 & 0.20 & -0.00 & -0.05 & & \\
\hline 10. Industry density & 41.3 & 23.2 & -0.01 & 0.12 & 0.29 & -0.01 & -0.01 & -0.04 & -0.04 & -0.14 & 0.03 & \\
\hline 11. Local corporate density & 29.3 & 23.9 & -0.08 & 0.05 & -0.10 & -0.02 & -0.10 & -0.08 & 0.01 & 0.07 & -0.29 & -0.14 \\
\hline \multicolumn{13}{|c|}{ B. Firms without institutional equivalents } \\
\hline Variable & Mean & SD & 1 & 2 & 3 & 4 & 5 & 6 & 7 & 8 & 9 & \\
\hline 1. Corporate philanthropic contributions & 1.64 & 10.7 & & & & & & & & & & \\
\hline 2. $C P C$ of industry peers & 1.43 & 3.40 & 0.10 & & & & & & & & & \\
\hline 3. CPC of local peers & 1.43 & 3.68 & 0.09 & 0.07 & & & & & & & & \\
\hline 4. Age & 18.1 & 13.3 & 0.09 & 0.18 & 0.12 & & & & & & & \\
\hline 5. Sales & 4,640 & 9,785 & 0.25 & 0.14 & 0.15 & 0.26 & & & & & & \\
\hline 6. $R O A$ & 0.05 & 0.05 & 0.01 & -0.00 & -0.00 & 0.01 & 0.02 & & & & & \\
\hline 7. Industry ROA & 0.05 & 0.03 & -0.01 & 0.04 & 0.00 & 0.05 & -0.01 & 0.10 & & & & \\
\hline 8. Community income & 34.5 & 8.16 & 0.08 & 0.12 & 0.35 & 0.10 & 0.24 & -0.01 & 0.00 & & & \\
\hline 9. Industry density & 31.8 & 25.1 & 0.01 & 0.30 & -0.07 & 0.01 & -0.02 & -0.03 & -0.05 & -0.04 & & \\
\hline 10. Local corporate density & 20.8 & 31.5 & -0.00 & -0.17 & 0.18 & -0.04 & -0.00 & 0.00 & 0.05 & 0.03 & -0.26 & \\
\hline
\end{tabular}

Notes. CPC and age were log-transformed for the purposes of regression analysis, but here we report means and standard deviations for the original untransformed variables (in millions of dollars and in years, respectively). To facilitate interpretation, sales and ROA were standardized for the purposes of regression analysis, but this table reports means and standard deviations for sales (in million dollars) and ROA before standardization.

\section{Results}

Descriptive statistics and correlations appear in Table 1, separately for firms that have institutional equivalents and those that do not. To compare these two types of firms, we conducted two-sample $t$-tests, which we corrected for unequal variances where appropriate. The two samples did not differ significantly in the average level of corporate giving, age, ROA, industry ROA, and community income. One statistically significant difference was that firms with institutional equivalents tended to be somewhat larger (by approximately $20 \%$ in terms of sales, on average; $P<0.001$ ). In addition, firms with institutional equivalents had more industry and community peers on average $(P<0.001)$, which is not surprising, because when the number of peers in the two fields is higher, there is naturally a higher chance of having some overlapping peers (i.e., institutional equivalents).

We test our hypotheses in Table 2. Focusing on firms with institutional equivalents, model 1 predicts the focal firm's philanthropic contributions as a function of its various peer groups' philanthropy and our control variables. Unsurprisingly, this model shows that firm size, firm age, and income level in the headquarters community are associated with greater philanthropic giving. More important for our purposes, this model provides evidence consistent with H1. There is a statistically significant relationship between the philanthropic giving of a firm's institutional equivalents and the firm's own giving; other industry and community peers, in contrast, do not have such an influence. This suggests that firms most closely follow their institutional equivalents, if they have them, while giving relatively little attention to cues from other industry and community peers.

Specifically, model 1 estimates that a $1 \%$ increase in institutional equivalents' average giving is associated with a roughly $0.12 \%$ subsequent increase in the focal firm's contributions, even when using a highly conservative modeling strategy with a two-year lag between the dependent and independent variables, firm and year fixedeffects, and a variety of control variables. As our tests of $\mathrm{H} 3-\mathrm{H} 5$ show below, this relationship is even stronger under certain conditions.

To explore how the situation differs when institutional equivalents do not exist, the second column of Table 2 presents a model that is similar to model 1 but focuses on firms without institutional equivalents. It shows that if a firm has no institutional equivalents, the philanthropic contributions of both its industry peers and its community peers are positively related to its own charitable contributions. Thus, such firms have fundamentally different imitation patterns than firms with institutional equivalents, 
Table 2 Hypothesis Tests: Fixed-Effects Models Predicting Corporate Philanthropic Contributions

\begin{tabular}{|c|c|c|c|c|c|}
\hline & Model $1(\mathrm{H} 1)$ & Model $2(\mathrm{H} 2)$ & Model $3(\mathrm{H} 3)$ & Model $4(\mathrm{H} 4)$ & Model $5(\mathrm{H} 5)$ \\
\hline CPC of institutional equivalents & $\begin{array}{l}0.12^{* * *} \\
(0.02)\end{array}$ & & $\begin{array}{l}0.14^{* * *} \\
(0.02)\end{array}$ & $\begin{array}{l}0.10^{* * *} \\
(0.02)\end{array}$ & $\begin{array}{l}0.12^{* * *} \\
(0.02)\end{array}$ \\
\hline CPC of industry peers & $\begin{array}{c}0.05 \\
(0.04)\end{array}$ & $\begin{array}{l}0.19^{* * *} \\
(0.03)\end{array}$ & $\begin{array}{c}0.06 \\
(0.04)\end{array}$ & $\begin{array}{c}0.05 \\
(0.04)\end{array}$ & $\begin{array}{c}0.05 \\
(0.04)\end{array}$ \\
\hline CPC of community peers & $\begin{array}{c}-0.03 \\
(0.05)\end{array}$ & $\begin{array}{l}0.11^{* * *} \\
(0.02)\end{array}$ & $\begin{array}{c}0.01 \\
(0.05)\end{array}$ & $\begin{array}{c}-0.01 \\
(0.05)\end{array}$ & $\begin{array}{c}-0.02 \\
(0.05)\end{array}$ \\
\hline CPC of institutional equivalents $\times$ Industry-community difference & & & $\begin{array}{c}0.08^{*} \\
(0.03)\end{array}$ & & \\
\hline$C P C$ of institutional equivalents $\times$ Sales & & & & $\begin{array}{l}0.08^{* * *} \\
(0.02)\end{array}$ & \\
\hline$C P C$ of institutional equivalents $\times R O A$ & & & & & $\begin{array}{r}-0.06^{+} \\
(0.03)\end{array}$ \\
\hline Sales (standardized) & $\begin{array}{l}1.23^{* * *} \\
(0.23)\end{array}$ & $\begin{array}{l}0.99^{* * *} \\
(0.26)\end{array}$ & $\begin{array}{l}1.24^{* * *} \\
(0.23)\end{array}$ & $\begin{array}{c}0.31 \\
(0.30)\end{array}$ & $\begin{array}{l}1.23^{* * *} \\
(0.23)\end{array}$ \\
\hline ROA (standardized) & $\begin{array}{c}-0.20 \\
(0.20)\end{array}$ & $\begin{array}{c}0.50 \\
(0.38)\end{array}$ & $\begin{array}{c}-0.20 \\
(0.20)\end{array}$ & $\begin{array}{c}-0.09 \\
(0.20)\end{array}$ & $\begin{array}{c}-0.01 \\
(0.23)\end{array}$ \\
\hline Age & $\begin{array}{l}1.02^{* * *} \\
(0.21)\end{array}$ & $\begin{array}{c}0.42^{+} \\
(0.22)\end{array}$ & $\begin{array}{l}1.01^{* * *} \\
(0.21)\end{array}$ & $\begin{array}{l}1.14^{* * *} \\
(0.21)\end{array}$ & $\begin{array}{l}1.02^{* * *} \\
(0.21)\end{array}$ \\
\hline $\begin{array}{l}\text { Industry ROA } \\
\text { Community income }\end{array}$ & $\begin{array}{c}0.45 \\
0.05^{*} \\
(0.02)\end{array}$ & $\begin{array}{c}-0.73^{*} \\
-0.04 \\
(0.03)\end{array}$ & $\begin{array}{c}0.29 \\
0.05^{*} \\
(0.02)\end{array}$ & $\begin{array}{c}0.19 \\
0.05^{*} \\
(0.02)\end{array}$ & $\begin{array}{c}0.94 \\
0.05^{*} \\
(0.02)\end{array}$ \\
\hline Industry density & $\begin{array}{c}-0.01 \\
(0.01)\end{array}$ & $\begin{array}{c}0.00 \\
(0.01)\end{array}$ & $\begin{array}{c}-0.01 \\
(0.01)\end{array}$ & $\begin{array}{c}-0.01 \\
(0.01)\end{array}$ & $\begin{array}{c}-0.01 \\
(0.01)\end{array}$ \\
\hline Community density & $\begin{array}{c}0.00 \\
(0.00)\end{array}$ & $\begin{array}{c}0.00 \\
(0.01)\end{array}$ & $\begin{array}{c}0.00 \\
(0.00)\end{array}$ & $\begin{array}{c}0.00 \\
(0.00)\end{array}$ & $\begin{array}{c}0.00 \\
(0.00)\end{array}$ \\
\hline Industry-community difference (standardized) & & & $\begin{array}{c}0.11 \\
(0.18)\end{array}$ & & \\
\hline Constant & $\begin{array}{c}0.06 \\
(1.49)\end{array}$ & $\begin{array}{l}4.22^{* *} \\
(1.46)\end{array}$ & $\begin{array}{c}-0.78 \\
(1.62)\end{array}$ & $\begin{array}{c}-0.50 \\
(1.49)\end{array}$ & $\begin{array}{c}0.02 \\
(1.49)\end{array}$ \\
\hline Observations: firm-years (firms) & $6,557(1,788)$ & $5,093(1,442)$ & $6,557(1,788)$ & $6,557(1,788)$ & $6,557(1,788)$ \\
\hline
\end{tabular}

Note. All models include firm and year fixed effects.

${ }^{+} p<0.10 ;{ }^{*} p<0.05 ;{ }^{* *} p<0.01 ;{ }^{* * *} p<0.001$.

which have a single obvious reference category of peers. This result provides support for $\mathrm{H} 2$.

\section{The Contingent Effect of Institutional Equivalents}

The last three models in Table 2 tests our hypotheses about conditions under which the influence of institutional equivalents is stronger or weaker $(\mathrm{H} 3, \mathrm{H} 4, \mathrm{H} 5)$.

Model 3 is similar to model 1 but adds our industrycommunity difference variable and its interaction with CPC of institutional equivalents. According to $\mathrm{H} 3$, when industry-community difference is high (i.e., when the average levels of giving in the industry and the community are dissimilar), we should see a particularly strong effect of institutional equivalents on the focal firm's giving. The results from model 3 are consistent with this prediction. When industry-community difference is one standard deviation below the mean (i.e., when the two peer groups are quite similar in their giving behavior), then institutional equivalents have only a weak effect; a $1 \%$ increase in their contributions is associated with a $0.06 \%$ (i.e., $0.14-0.08=0.06$ ) increase in the focal firm's giving. However, when industry-community difference is one standard deviation above the mean (i.e., when the two peer groups are quite different in their giving levels), a $1 \%$ increase in institutional equivalent's giving has an effect that is more than three time as strong, leading to a $0.22 \%$ (i.e., $0.14+0.08=0.22$ ) increase in the focal firm's giving. Figure 4 plots this interaction effect. Thus, consistent with $\mathrm{H} 3$, the greater the difference between the philanthropic contribution levels of industry peers and community peers, the greater the influence of institutional equivalents on a firm's contributions.

Model 4 tests H4, examining whether the influence of institutional equivalents varies with the size of the focal firm. Consistent with our prediction, the coefficient on the interaction between $C P C$ of institutional equivalents and sales is positive and statistically significant, implying that the larger the firm, the stronger the effect of institutional equivalents on its philanthropic contributions. This relationship is depicted in Figure 5. This finding suggests that large, highly visible organizations are especially likely to look to their institutional equivalents. 
Figure 4 Industry-Community Difference, Institutional Equivalents, and Philanthropy (H3)

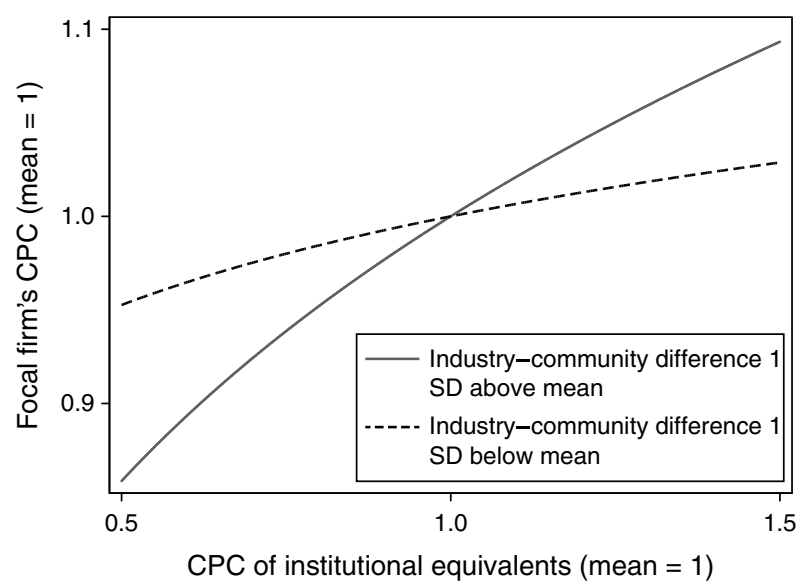

Finally, model 5 tests our hypothesis that the influence of institutional equivalents is somewhat weaker for financially high-performing firms (H5). The coefficient on the interaction term between ROA and the contributions of institutional equivalents is positive and significant at the $10 \%$ level (two-way test), providing some evidence that the higher the financial performance of a firm, the weaker the influence of institutional equivalents on its philanthropic contributions. Figure 6 displays this relationship.

\section{Supplementary Analyses: Firms Without Institutional Equivalents}

Though we did not hypothesize how industry-community difference, firm size, and ROA might shape firms' imitation patterns in the absence of institutional equivalents, we conducted supplementary analyses to explore this question in Table 3. This analysis examines whether a firm that has no institutional equivalents pays more or less attention to its industry and community peers depending on the difference between the two peer groups' giving

Figure 5 Firm Size, Institutional Equivalents, and Philanthropy (H4)

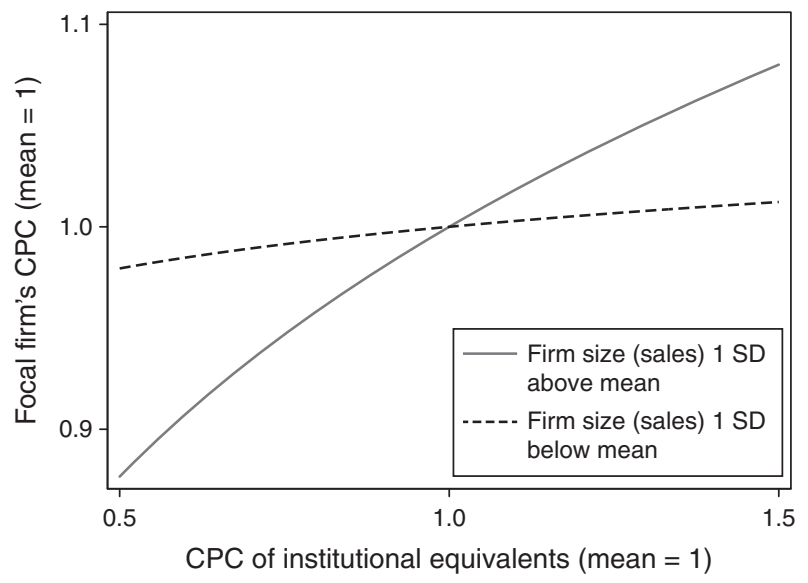

Figure 6 Firm Performance, Institutional Equivalents, and Philanthropy (H5)

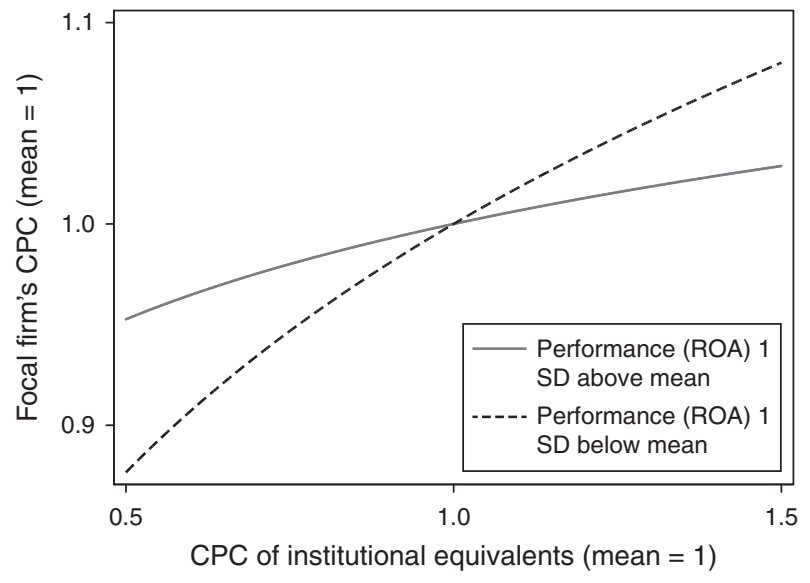

levels (models 6 and 7), firm size (model 8), and financial performance (model 9).

Models 6 and 7 include interactions between industrycommunity difference and industry peers' giving (model 6) and community peers' giving (model 7). We included these two interactions in separate regressions because variance inflation factors indicated serious collinearity problems when including these interactions in the same model. Model 6 indicates that the lower the industrycommunity difference (i.e., the more similar the level of giving in the industry and the community), the stronger the effect of industry peers. Similarly, model 7 shows that the link between the CPC of community peers and the focal firm's giving is strongest when the level of giving among community peers is consistent with the level of giving among industry peers (i.e., when industrycommunity difference is low). This suggests that-in the absence of institutional equivalents-when different fields give rise to inconsistent cues and pull the focal organization in different directions, those dissimilar cues might weaken one another. In contrast, it seems that when the cues arising from different fields are in alignment with one another (when industry-community difference is low), organizations without institutional equivalents are particularly responsive to the mutually reinforcing cues from their industry and community peers. In addition, model 8 suggests that in the absence of institutional equivalents, larger firms are especially attentive to both their industry peers and their community peers. Financial performance, in contrast, has no significant bearing on the imitation of either industry or community peers among firms in an institutionally unique position (model 9).

Overall, our results suggest that when firms have institutional equivalents, they most closely follow this single obvious reference group and are less likely to be affected by the level of philanthropy among their other industry and community peers. But the influence of institutional equivalents is not uniform across all firms and situations; it is particularly strong if inconsistent cues emerge from 
Table 3 Supplementary Analysis: Models Predicting Corporate Philanthropic Contributions

\begin{tabular}{|c|c|c|c|c|}
\hline & Model 6 & Model 7 & Model 8 & Model 9 \\
\hline CPC of industry peers & $\begin{array}{l}0.21^{* * *} \\
(0.03)\end{array}$ & $\begin{array}{l}0.21^{* * *} \\
(0.03)\end{array}$ & $\begin{array}{l}0.17^{* * *} \\
(0.03)\end{array}$ & $\begin{array}{l}0.19^{* * *} \\
(0.03)\end{array}$ \\
\hline CPC of community peers & $\begin{array}{l}0.09 * * * \\
(0.02)\end{array}$ & $\begin{array}{l}0.09 * * * \\
(0.02)\end{array}$ & $\begin{array}{l}0.10^{* * * *} \\
(0.02)\end{array}$ & $\begin{array}{l}0.11^{* * *} \\
(0.02)\end{array}$ \\
\hline CPC of industry peers $\times$ Industry-community difference & $\begin{array}{l}-0.02^{* * *} \\
(0.01)\end{array}$ & & & \\
\hline CPC of community peers $\times$ Industry-community difference & & $\begin{array}{l}-0.02^{* * *} \\
(0.01)\end{array}$ & & \\
\hline CPC of industry peers $\times$ Sales & & & $\begin{array}{l}0.11^{* * *} \\
(0.03)\end{array}$ & \\
\hline CPC of community peers $\times$ Sales & & & $\begin{array}{l}0.11^{* * *} \\
(0.02)\end{array}$ & \\
\hline$C P C$ of industry peers $\times R O A$ & & & & $\begin{array}{c}0.03 \\
(0.11)\end{array}$ \\
\hline$C P C$ of community peers $\times R O A$ & & & & $\begin{array}{r}-0.02 \\
(0.09)\end{array}$ \\
\hline Sales (standardized) & $\begin{array}{l}0.98^{* * *} \\
(0.26)\end{array}$ & $\begin{array}{l}0.96 * * * \\
(0.26)\end{array}$ & $\begin{array}{c}-1.78^{* *} \\
(0.58)\end{array}$ & $\begin{array}{l}0.99^{* * *} \\
(0.26)\end{array}$ \\
\hline ROA (standardized) & $\begin{array}{c}0.51 \\
(0.38)\end{array}$ & $\begin{array}{c}0.52 \\
(0.38)\end{array}$ & $\begin{array}{c}0.53 \\
(0.38)\end{array}$ & $\begin{array}{c}0.38 \\
(1.94)\end{array}$ \\
\hline Age & $\begin{array}{c}0.42 \\
(0.22)\end{array}$ & $\begin{array}{c}0.41 \\
(0.22)\end{array}$ & $\begin{array}{l}0.59^{* *} \\
(0.23)\end{array}$ & $\begin{array}{c}0.41 \\
(0.22)\end{array}$ \\
\hline Industry ROA & $\begin{array}{c}-0.56 \\
(0.34)\end{array}$ & $\begin{array}{l}-0.60 \\
(0.34)\end{array}$ & $\begin{array}{r}-0.69^{*} \\
(0.34)\end{array}$ & $\begin{array}{r}-0.73^{*} \\
(0.34)\end{array}$ \\
\hline Community income & $\begin{array}{r}-0.05 \\
(0.03)\end{array}$ & $\begin{array}{r}-0.05 \\
(0.03)\end{array}$ & $\begin{array}{r}-0.05 \\
(0.03)\end{array}$ & $\begin{array}{r}-0.04 \\
(0.03)\end{array}$ \\
\hline Industry density & $\begin{array}{c}-0.00 \\
(0.01)\end{array}$ & $\begin{array}{c}-0.00 \\
(0.01)\end{array}$ & $\begin{array}{c}0.00 \\
(0.01)\end{array}$ & $\begin{array}{c}0.00 \\
(0.01)\end{array}$ \\
\hline Community density & $\begin{array}{c}0.00 \\
(0.01)\end{array}$ & $\begin{array}{c}0.00 \\
(0.01)\end{array}$ & $\begin{array}{c}0.00 \\
(0.01)\end{array}$ & $\begin{array}{c}0.00 \\
(0.01)\end{array}$ \\
\hline Industry-community difference (standardized) & $\begin{array}{c}0.19 \\
(0.19)\end{array}$ & $\begin{array}{c}0.31 \\
(0.19)\end{array}$ & & \\
\hline Constant & $\begin{array}{c}4.31^{* *} \\
(1.46)\end{array}$ & $\begin{array}{c}4.00^{* *} \\
(1.46)\end{array}$ & $\begin{array}{c}3.86^{* *} \\
(1.46)\end{array}$ & $\begin{array}{c}4.23^{* *} \\
(1.46)\end{array}$ \\
\hline Observations: firm-years (firms) & $5,093(1,442)$ & $5,093(1,442)$ & $5,093(1,442)$ & $5,093(1,442)$ \\
\hline
\end{tabular}

Note. All models include firm and year fixed effects. ${ }^{*} p<0.05 ;{ }^{* *} p<0.01 ;{ }^{* * *} p<0.001$.

the focal firm's industry and community, if the firm is a large, visible organization, or if its financial performance is relatively weak. In contrast, firms without institutional equivalents are in a distinctly different situation. As they lack a single obvious category of imitable peers, they pay attention to both their industry peers and their community peers, especially if the cues from those peer groups are consistent, and if the focal firm is large. Taken together, these findings suggest that organizations with and without institutional equivalents exhibit fundamentally different patterns of intraorganizational imitation, and that institutional equivalents - when they exist - constitute a critically important part of a firm's institutional environment.

\section{Discussion}

Organizational theorists are increasingly interested in understanding how organizations operate in multifaceted environments composed of other organizations and diverse institutional influences (Pache and Santos 2010,
Wry et al. 2013). Within institutional theory, while a significant focus has been how and why an organization imitates other organizations that operate in the same field, more recent research has drawn attention to multiple institutional influences, highlighting the fact that many organizations are embedded in more than just one field.

Our study reveals the implications of this situation by introducing the concept of institutional equivalence and showing that when institutional equivalents exist, they serve as an obvious reference category such that firms will pay relatively little attention to other peers with which they share only a single field. Furthermore, when the behaviors of peers in the different fields diverge and so firms experience more uncertainty, they are even more likely to follow their institutional equivalents. In contrast, organizations in an institutionally unique position lack a single obvious reference group of imitable peers and thus attend to behavioral cues from both their community peers and their industry peers. Our supplementary analyses further showed that when the behavioral cues 
from the different fields diverge, firms without institutional equivalents are less likely to imitate the behavior of either peer group. Finally, we further unpack the effect of institutional equivalents by considering how their influence varies depending on two basic characteristics of the focal organization and showing that larger size amplifies, while stronger performance attenuates, the imitation of institutional equivalents.

A crucial implication of our theory and findings is that without identifying institutional equivalents, prior literature may have overgeneralized or misspecified the extent to which firms follow different types of peers. For example, studies that examine either industry-based (e.g., Fligstein 1985) or community-based (e.g., Marquis 2003) imitation typically only include the behavior of that one set of peers. For instance, while Marquis (2003) argued that new firms in a community imitated the board of director structures of prominent local firms, he did not take into account how this apparent attention to local peers might be confounded by the imitation of industry peers or the effect of institutional equivalents. Our findings suggest that to properly identify effects of a focal group of peers, researchers must not only identify that particular group of peers, but also examine whether and how it overlaps with other important peer groups; that is, institutional equivalents represent a special and particularly influential subset of peers, and this group cannot be identified without examining the overlap of the different fields in which the focal firm is embedded. And, when there is no such overlap, because institutional equivalents do not exist, the focal firm is all the more attentive to both fields. Thus, without considering the influence of institutional equivalents, research on mimetic isomorphism that only considers the effects of single fields may be incomplete and even potentially misleading. We call for future research on interorganizational imitation that does not simply focus on peers in a given field, but, rather, examines the wider set of relevant and potentially overlapping peer groups.

The notion that organizations are especially attuned to the behavior of their institutional equivalents also relates to the idea, elaborated in the ecology literature, that firms are most likely to imitate similar others (Haveman 1993, Greve 1998). However, we emphasize a different dimension of similarity that shapes imitation patterns-location at the same intersection of two fields. This dimension of similarity is based not only on the strategic aspects of a firm's situation-such as firm size or market typebut also on embeddedness in the same sociocultural context of a local headquarters community (Marquis and Battilana 2009). Thus, this type of similarity fosters imitation of other firms whose institutional situation is similar to the focal firm's own. While scholars commonly recognize that there is significant "heterogeneity in imitation" (Greve 2000, p. 818) in the sense that not all firms are equally likely to be imitated, research in this area has typically focused on heterogeneity in imitation by firm type (e.g., Haveman 1993; for a review, see Greve 2000) or location (Marquis and Battilana 2009). In contrast, we shed light on how the specific constellation of peer groups that a firm has-and, in particular, whether those groups are intersecting or not-affects imitation patterns.

In addition, our findings about the effects of size and performance on how closely firms follow institutional equivalents contributes to a greater understanding of how organizational characteristics "filter" institutional cues (Greenwood et al. 2011, Martin 2003). While the existing literature has begun to consider how organizational filters affect the adoption of different practices (e.g., Raffaelli and Glynn 2014, Tilcsik 2010), it has not explored the effect of organizational characteristics on how closely an organization attends to the behavior of its peers. Our findings regarding organizational performance illustrate why this distinction is conceptually important. While research suggests that better performing firms may donate more (Waddock and Graves 1997), we hypothesize and show that performance also leads firms to be less likely to imitate the donation patterns of their peers. Thus, the previous focus on how filters affect the adoption of practices is insufficient for understanding the organizational contingencies of institutional processes (Greenwood et al. 2011, Martin 2003). We encourage future research to continue examining how organizational characteristics affect imitation patterns.

While simultaneous embeddedness in an industry and a geographic community is a ubiquitous organizational condition, the concept of institutional equivalence also has implications for other situations and thus contributes to institutional theory more generally as well. For example, as globalization proceeds, corporations with a wide global spread might have several geographically based reference groups in addition to peers in their industry and their headquarters community (Kostova and Roth 2002). This suggests that understanding effects of multiple reference groups on firms will be an increasingly important topic from both theoretical and practical standpoints. Furthermore, research has shown that firms' virtual communities are also potentially important sources of institutional influences (Almandoz et al. 2016). Thus, in some cases, institutional cues might emanate from three or even more fields. The implications of our framework, however, remain the same: to understand how organizations respond to such conditions, researchers must examine whether a firm has institutional equivalents and whether behavioral cues from the various fields are consistent or divergent. Future research that directly explores this issue could further elaborate our arguments and yield additional insights.

Our framework might also apply to situations when inconsistent institutional influences are present within one of the fields in which an organization operates. For example, fields that are just emerging or undergoing a radical 
transformation-such as new industries or those experiencing significant flux - are often characterized by sharp contestation between different institutions (Greenwood et al. 2011). One idea that might emerge from our framework is that the lack of a clear and unambiguous signal about appropriate behaviors will render internally contested fields less relevant, thus making internally stable fields, or those that have reached a "settlement" (Rao and Kenney 2008, Smets et al. 2012), relatively more important in shaping the behavior of organizations. Furthermore, while our analysis did not focus on firms that faced different institutional logics (Thornton et al. 2012), our concept of institutional equivalence might be relevant to understanding situations where firms face multiple logics, and exploring such situations is an important step for future work. For instance, within-field contestation about multiple logics might attract more intense attention to a field and hence increase its relative salience, or it might increase uncertainty and thus make institutional equivalents particularly important. These possible implications of our theory deserve empirical attention at the withinfield level, and exploring how they affect situations where multiple logics exist should help clarify the link between conflicting institutional influences that are due to embeddedness in multiple fields and those that exist within a field.

\section{Boundaries, Limitations, and Future Research}

As with any study, there are boundaries to our theorizing and limitations to our approach that we hope future research will address. First, a reasonable question concerns the extent to which our study of corporate philanthropy may generalize to other organizational activities. In particular, corporate philanthropy has been shown to be a relatively discretionary practice with questionable financial impact (Margolis and Walsh 2003), and not typically driven by core business considerations (Marquis and Lee 2013). Thus, one possible boundary condition is that some aspects of our theory may apply particularly well to discretionary practices. At the same time, other studies have shown that even core business activities, such as financing and market exit decisions, are sensitive to similar institutional processes (Mizruchi et al. 2006, Gaba and Terlaak 2013), suggesting that such effects may apply more broadly. Furthermore, while philanthropy is often seen as a largely local phenomenon (Galaskiewicz 1997), we note that many other organizational practicesfrom firm strategy (Lounsbury 2007) to corporate governance (Davis and Greve 1997, Marquis 2003) - have also been shown to be powerfully influenced by local peers. Future research, however, should examine potential boundary conditions to our theory, exploring different types of organizational practices and their relationship to different institutional environments.

In addition, we recognize the limitations of different empirical approaches and acknowledge that our largescale, longitudinal, quantitative methods cannot provide deep insight into the fine-grained microfoundations of the patterns we uncovered. In particular, while we do see imitation as a response to uncertainty about what is legitimate and appropriate in general and about how much giving is "enough" in particular, we do not observe the specific motivations behind these imitation processes. We encourage more qualitative research into our questions, in part to better understand the motivations behind institutional processes. Importantly, qualitative studies could reveal the details of the within-organizational processes whereby firms manage their embeddedness in multiple fields (Almandoz 2014).

Furthermore, future work might examine situations when one field versus the other may take precedence for an organization because of certain characteristics of the field or the organization (Zhang et al. 2016). Prior research has suggested a number of community and industry field characteristics that affect firms' susceptibility to behavioral cues. For example, some communities have a deeper tradition of localism (Marquis 2003), and the presence of upper-class social clubs (Domhoff 2010, Kono et al. 1998) and a vibrant nonprofit sector (Marquis et al. 2007) may strengthen community effects. Studies have also shown that isomorphism varies across different industries (Galaskiewicz 1997, Lev et al. 2010) and depends on factors such customer type (Burt 1983) and level of industry concentration (Guillén 2002). We recommend further research into how different field-level and organization-level characteristics affect the salience of one field versus another.

Finally, with regard to our empirical context, future research might examine the extent to which the drivers of corporate philanthropy have changed over time and how that may affect responses to multiple institutional influences. In recent years, for example, there has been a shift toward "strategic philanthropy" that targets "areas of competitive context where the company and society both benefit" (Porter and Kramer 2002, p. 58). We accounted for such changes through our methods, including the use of year fixed effects to capture broad trends, but we also believe that one interesting future research effort would be to explore how the changing motivation for philanthropy might shape the imitation patterns we have explored.

\section{Conclusion}

Most organizations simultaneously exist in multiple fields and face several institutional influences as a result. While recent research has identified the importance of different institutional forces on organizations, limited attention has focused on how organizations address their enduring embeddedness in multiple distinct fields, such as industrybased fields and local communities. To understand this ubiquitous situation, we have introduced the concept of institutional equivalence and developed a framework that considers the nature of the position that the focal organization occupies at the intersection of different fields. 
This framework provides a new lens for understanding the consequences of embeddedness in multiple fieldsa pervasive organizational condition that merits further study.

\section{Acknowledgments}

The authors thank Senior Editor Willie Ocasio and three anonymous reviewers for their guidance through the review process, and John Almandoz, Julie Battilana, Marya Besharov, Frank Dobbin, Vince Feng, Shon Hiatt, Kim Pernell, Ryan Raffaelli, Mia Raynard, Sameer Srivastava, Pam Tolbert, and Lynn Yin, as well as audience members at Cornell University, Dartmouth, Indiana University, the University of Pennsylvania, the University of Southern California, and the ABC network conference in Banff, Alberta, for comments on a previous version of this paper. This research was partially supported by a grant from the Michael Lee-Chin Family Institute for Corporate Citizenship.

\section{Endnotes}

${ }^{1}$ The concept of institutional equivalence is different from structural equivalence. Structurally equivalent actors have structurally identical relational patterns and positions in a network (Mizruchi 1993). Institutional equivalence, on the other hand, captures the similarity of institutional influences that organizations experience from being in the same fields, regardless of how similar their network ties and positions are. For example, two banks in Boston might have very different patterns of ties (e.g., one may be a central node surrounded by a dense network; the other may reside in a peripheral position in a sparser network) such that they are far from being structural equivalents; yet, because they both operate in the field of finance and in the same geographically defined field, they are subject to some of the same institutional influences.

${ }^{2}$ Because new firms emerge and some old firms disappear over time, this data set represents an unbalanced panel. A battery of standard econometric tests using different selection variables (Nijman and Verbeek 1992, Wooldridge 2002, Verbeek 2008) indicated no selection bias due to this issue.

${ }^{3}$ Significant diversification across two-digit SIC codes was uncommon during most of our period, and our results remained substantively unchanged when we controlled for diversification across two-digit SIC codes using the entropy measure (Davis et al. 1994).

\section{References}

Almandoz J (2012) Arriving at the starting line: The impact of community and financial logics on new banking ventures. Acad. Management J. 55(6):1381-1406.

Almandoz J (2014) Founding teams as carriers of competing logics: When institutional forces predict banks' risk exposure. Admin. Sci. Quart. 59(3):442-473.

Almandoz J, Marquis C, Cheely M (2016) Drivers of community strength: An institutional logics perspective on geographical and affiliation based communities. Greenwood R, Oliver C, Lawrence TB, Renate M, eds. The Sage Handbook of Organizational Institutionalism, 2nd ed. (Sage, New York). Forthcoming.

Audia PG, Freeman JH, Reynolds PD (2006) organizational foundings in community context: Instruments manufacturers and their interrelationship with other organizations. Admin. Sci. Quart. 51(3):381-419.
Battilana J, Dorado S (2010) building sustainable hybrid organizations: The case of commercial microfinance organizations. Acad. Management J. 53(6):1419-1440.

Beckman CM, Haunschild PR (2002) Network learning: The effects of partners' heterogeneity of experience on corporate acquisitions. Admin. Sci. Quart. 47(1):92-124.

Bertels S, Peloza J (2008) Running just to stand still? Managing CSR reputation in an era of ratcheting expectations. Corporate Reputation Rev. 11(1):56-72.

Besharov ML, Smith WK (2014) Multiple institutional logics in organizations: Explaining their varied nature and implications. Acad. Management Rev. 39(3):364-381.

Block P, Grund T (2014) Multidimensional homophily in friendship networks. Network Sci. 2(2):189-212.

Brammer S, Millington A (2005) Corporate reputation and philanthropy: An empirical analysis. J. Bus. Ethics 61(1):29-44.

Brammer S, Millington A (2006) Firm size, organizational visibility and corporate philanthropy: An empirical analysis. Bus. Ethics: Eur. Rev. 15(1):6-18.

Burt RS (1983) Corporate philanthropy as a cooptive relation. Soc. Forces 62(2):419-449.

Coady M (2008) Giving in Numbers: 2008 Edition (The Committee Encouraging Corporate Philanthropy, New York).

Cyert RM, March JG (1963) A Behavioral Theory of the Firm (Prentice Hall, Englewood Cliffs, NJ).

Davis GF (2010) Do theories of organizations progress? Organ. Res. Methods 13(4):690-709.

Davis GF, Greve HR (1997) Corporate elite networks and governance changes in the 1980s. Amer. J. Sociol. 103(1):1-37.

Davis GF, Diekmann KA, Tinsley CH (1994) The decline and fall of the conglomerate firm in the 1980s: The deinstitutionalization of an organizational form. Amer. Sociol. Rev. 59(4):547-570.

Deephouse DL (1996) Does isomorphism legitimate? Acad. Management J. 39(4):1024-1039.

DiMaggio PJ, Powell WW (1983) The iron cage revisited: Institutional isomorphism and collective rationality in organizational fields. Amer. Sociol. Rev. 48(2):147-160.

Domhoff GW (2010) Who Rules America? Power and Politics, and Social Change (McGraw-Hill, Boston).

Dunn MB, Jones C (2010) Institutional logics and institutional pluralism: The contestation of care and science logics in medical education, 1967-2005. Admin. Sci. Quart. 55(1):114-149.

Elkind P (2016) The man who sold Silicon Valley on giving. Fortune (August 24), http://fortune.com/2016/08/24/peter-hero -silicon-valley-giving/.

Fitzpatrick D (2006) As steel shaped Pittsburgh, banking defines Charlotte. Pittsburgh Post-Gazette (June 27), http://fortune.com/ 2016/08/24/peter-hero-silicon-valley-giving/.

Fligstein N (1985) Spread of the multidividional form among large firms, 1919-1979. Amer. Sociol. Rev. 50(3):377-391.

Foundation Center, The (1981-2007) National Directory of Corporate Giving. The Foundation Center, New York.

Freeman JH, Audia PG (2006) Community ecology and the sociology of organizations. Annual Rev. Sociol. 32(August):145-169.

Friedland R, Alford RR (1991) Bringing society back in: Symbols, practices and institutional contradictions. Powell WW, DiMaggio PJ, eds. The New Institutionalism in Organizational Analysis (University of Chicago Press, Chicago), 232-262.

Friedman M (1970) The social responsibility of business is to increase its profits. New York Times Magazine (September 13), 33, 122-126.

Gaba V, Terlaak A (2013) Decomposing uncertainty and its effects on imitation in firm exit decisions. Organ. Sci. 24(6):1847-1869. 
Galaskiewicz J (1985) Social Organization of an Urban Grants Economy: A Study of Business Philanthropy and Nonprofit Organizations (Academic Press, Orlando, FL).

Galaskiewicz J (1997) An urban grants economy revisited: Corporate charitable contributions in the Twin Cities, 1979-81, 1987-89. Admin. Sci. Quart. 42(3):445-471.

Gertner R, Powers E, Scharfstein D (2002) Learning about internal capital markets from corporate spin-offs. J. Finance 57(6): 2479-2506.

Glynn MA, Abzug R (2002) Institutionalizing identity: Symbolic isomorphism and organizational names. Acad. Management J. 45(1):267-280.

Greenwood R, Meyer RE (2008) Influencing ideas a celebration of DiMaggio and Powell (1983) J. Management Inquiry 17(4): 258-264.

Greenwood R, Suddaby R (2006) Institutional entrepreneurship in mature fields: The Big Five accounting firms. Acad. Management J. 49(1):27-48.

Greenwood R, Raynard M, Kodeih F, Micelotta ER, Lounsbury M (2011) Institutional complexity and organizational responses. Acad. Management Ann. 5(1):317-371.

Greve HR (1998) Managerial cognition and the mimetic adoption of market positions: What you see is what you do. Strategic Management J. 19(10):967-988.

Greve HR (2000) Market niche entry decisions: Competition, learning, and strategy in Tokyo banking, 1894-1936. Acad. Management J. 43(5):816-836.

Greve HR (2005) Interorganizational learning and heterogeneous social structure. Organ. Stud. 26(7):1025-1047.

Guillén MF (2002) Structural inertia, imitation, and foreign expansion: South Korean firms and business groups in China, 1987-1995. Acad. Management J. 45(3):509-525.

Hankins M (2007) Bank vs. Bank. Charlotte Magazine (September 30), http://www.charlottemagazine.com/Charlotte -Magazine/September-2007/Bank-vs-Bank/.

Haunschild PR, Miner AS (1997) Modes of interorganizational imitation: The effects of outcome salience and uncertainty. Admin. Sci. Quart. 42(3):472-500.

Haveman HA (1993) Follow the leader: Mimetic isomorphism and entry into new markets. Admin. Sci. Quart. 38(4):593-627.

Hemingway CA, Maclagan PW (2004) Managers' personal values as drivers of corporate social responsibility. J. Bus. Ethics 50(1): $33-44$.

Henisz WJ, Delios A (2001) Uncertainty, imitation, and plant location: Japanese multinational corporations, 1990-1996. Admin. Sci. Quart. 46(3):443-475.

King BG (2008) A political mediation model of corporate response to social movement activism. Admin. Sci. Quart. 53(3):395-421.

Klepper S (2007) Disagreements, spinoffs, and the evolution of Detroit as the capital of the U.S. automobile industry. Management Sci. 53(4):616-631.

Kono C, Palmer D, Friedland R, Zafonte M (1998) Lost in space: The geography of corporate interlocking directorates. Amer. J. Sociol. 103(4):863-911.

Kostova T, Roth K (2002) Adoption of an organizational practice by subsidiaries of multinational corporations: Institutional and relational effects. Acad. Management J. 45(1):215-233.

Kraatz M, Block ES (2008) Organizational implications of institutional pluralism. Greenwood R, Oliver C, Suddaby R, Sahlin-Andersson K, eds. The Sage Handbook of Organizational Institutionalism (Sage Publications, London), 243-275.
Lant TK, Baum JAC (1995) Cognitive sources of socially constructed competitive groups: Examples from the Manhattan hotel industry. Scott WR, Christensen S, eds. The Institutional Construction of Organizations (Sage, Thousand Oaks, CA), 15-38.

Lev B, Petrovits C, Radhakrishnan S (2010) Is doing good good for you? How corporate charitable contributions enhance revenue growth. Strategic Management J. 31(2):182-200.

Lounsbury M (2007) A tale of two cities: Competing logics and practice variation in the professionalizing of mutual funds. Acad. Management J. 50(2):289-307.

Margolis JD, Walsh JP (2003) Misery loves companies: Rethinking social initiatives by business. Admin. Sci. Quart. 48(2):268-305.

Marquis C (2003) The pressure of the past: Network imprinting in intercorporate communities. Admin. Sci. Quart. 48(4):655-689.

Marquis C, Battilana J (2009) Acting globally but thinking locally? The influence of local communities on organizations. Res. Organ. Behav. 29(December):283-302.

Marquis C, Lee M (2013) Who is governing whom? Executives, governance, and the structure of generosity in large U.S. firms. Strategic Management J. 34(4):483-497.

Marquis C, Davis GF, Glynn MA (2013) Golfing alone? Corporations, elites and nonprofit growth in 100 American communities. Organ. Sci. 24(1):39-57.

Marquis C, Glynn MA, Davis GF (2007) Community isomorphism and corporate social action. Acad. Management Rev. 32(July):925-945.

Martin JL (2003) What is field theory? Amer. J. Sociol. 109(1):1-49.

McDonnell MH, King B (2013) Keeping up appearances: Reputational threat and impression management after social movement boycotts. Admin. Sci. Quart. 58(3):387-419.

McWilliams A, Siegel D (2001) Corporate social responsibility: A theory of the firm perspective. Acad. Management Rev. 26(1): $117-127$.

Mizruchi MS (1993) Cohesion, equivalence, and similarity of behavior: A theoretical and empirical assessment. Soc. Networks 15(3):275-307.

Mizruchi MS, Stearns LB, Marquis C (2006) The conditional nature of embeddedness: A study of borrowing by large U.S. firms, 1973-1994. Amer. Sociol. Rev. 71(2):310-333.

Moody J (2001) Race, school integration, and friendship segregation in America. Amer. J. Sociol. 107(3):679-716.

Nijman T, Verbeek M (1992) Nonresponse in panel data: The impact on estimates of a life cycle consumption function. J. Appl. Econometrics 7(3):243-257.

Ocasio W (1999) Institutionalized action and corporate governance: The reliance on rules of CEO succession. Admin. Sci. Quart. 44(4):384-416.

Oliver C (1991) Strategic responses to institutional processes. Acad. Management Rev. 16(1):145-179.

Owen-Smith J, Powell WW (2004) Knowledge networks as channels and conduits: The effects of spillovers in the Boston biotechnology community. Organ. Sci. 15(1):5-21.

Pache AC, Santos F (2010) When worlds collide: The internal dynamics of organizational responses to conflicting institutional demands. Acad. Management Rev. 35(3):455-476.

Pache AC, Santos F (2013) Inside the hybrid organization: Selective coupling as a response to conflicting institutional logics. Acad. Management J. 56(4):972-1001.

Palmer DA, Jennings PD, Zhou X (1993) Late adoption of the multidivisional form by large U.S. corporations: Institutional, political, and economic accounts. Admin. Sci. Quart. 38(1):100-131.

Porter ME, Kramer MR (2002) The competitive advantage of corporate philanthropy. Harvard Bus. Rev. 80(12):56-68. 
Purdy JM, Gray B (2009) Conflicting logics, mechanisms of diffusion, and multilevel dynamics in emerging institutional fields. Acad. Management J. 52(2):355-380.

Raffaelli R, Glynn MA (2014) Turnkey or tailored? Relational pluralism, institutional complexity, and the organizational adoption of more or less customized practices. Acad. Management J. 57(2):541-562.

Raffaelli R, Glynn MA, Pedersen JS (2013) Towards a general theory of the institutional field. Working paper, Harvard Business School, Boston.

Rao H, Kenney M (2008) New forms as settlements. Greenwood $\mathrm{R}$, Oliver C, Sahlin-Andersson K, Suddaby R, eds. The Sage Handbook of Organizational Institutionalism (Sage, London), 352-370.

Rao H, Greve HR, Davis GF (2001) Fool's gold: Social proof in the initiation and abandonment of coverage by Wall Street analysts. Admin. Sci. Quart. 46(3):502-526.

Reay T, Hinings CR (2009) Managing the rivalry of competing institutional logics. Organ. Stud. 30(6):629-652.

Romanelli E, Khessina OM (2005) Regional industrial identity: Cluster configurations and economic development. Organ. Sci. 16(4):344-358.

Rowan B (1982) Organizational structure and the institutional environment: The case of public schools. Admin. Sci. Quart. 27(2): 259-279.

Saxenian AL (1994) Regional Advantage: Culture and Competition in Silicon Valley and Route 128 (Harvard University Press, Cambridge, MA).

Schneiberg M, Clemens ES (2006) The typical tools for the job: Research strategies in institutional analysis. Soc. Theory 24(3): 195-227.

Scott WR (2001) Institutions and Organizations, 2nd ed. (Sage Publications, Thousand Oaks, CA).

Scott WR, Ruef M, Mendel PJ, Caronna CA (2000) Institutional Change and Healthcare Organizations: From Professional Dominance to Managed Care (University of Chicago Press, Chicago).

Seo MG, Creed WD (2002) Institutional contradictions, praxis, and institutional change: A dialectical perspective. Acad. Management Rev. 27(2):222-247.

Siegfried JJ, McElroy KM, Biemot-Fawkes D (1983) The management of corporate contributions. Preston LE, ed. Research in Corporate Social Performance and Policy: An Annual Compilation of Research (JAI Press, Greenwich, CT), 87-102.

Smets MT, Morris I, Greenwood R (2012) From practice to field: A multilevel model of practice-driven institutional change. Acad. Management J. 55(4):877-904.

Strang D, Macy MW (2001) In search of excellence: Fads, success stories, and adaptive emulation. Amer. J. Sociol. 107(1):147-182.

Sull DN (1999) The dynamics of standing still: Firestone tire and rubber and the radial revolution. Bus. History Rev. 73(3): 430-464.

Thornton PH, Ocasio W (1999) Institutional logics and the historical contingency of power in organizations: Executive succession in the higher education publishing industry, 1958-1990. Amer. J. Sociol. 105(3):801-843.

Thornton PH, Ocasio W, Lounsbury M (2012) The Institutional Logics Perspective: A New Approach to Culture, Structure, and Process (Oxford University Press, Oxford, UK).
Tilcsik A (2010) From ritual to reality: Demography, ideology, and decoupling in a post-communist government agency. Acad. Management J. 53(6):1474-1498.

Tilcsik A, Marquis C (2013) Punctuated generosity: How mega-events and natural disasters affect corporate philanthropy in U.S. communities. Admin. Sci. Quart. 58(1):111-148.

U.S. Census Bureau (2010) About metropolitan and micropolitan statistical areas. Online archives, Accessed December 9, 2016, http://www.census.gov/population/metro/.

Useem M (1988) Market and institutional factors in corporate contributions. California Management Rev. 30(2):77-88.

Useem M, Kutner SI (1986) Corporate contributions to culture and the arts: The organization of giving and the influence of the chief executive officer and of other firms on company contributions in Massachusetts. DiMaggio PJ, ed. Nonprofit Enterprise in the Arts: Studies in Mission and Constraint (Oxford University Press, New York), 93-112.

Verbeek M (2008) A Guide to Modern Econometrics, 3rd ed. (John Wiley \& Sons, Chichester, UK).

Waddock SA, Graves SB (1997) The corporate social performance financial performance link. Strategic Management J. 18(4): 303-319.

Warren RL (1967) The interorganizational field as a focus for investigation. Admin. Sci. Quart. 12(3):396-419.

Westphal JD, Zajac EJ (1994) Substance and symbolism in CEOs' long-term incentive plans. Admin. Sci. Quart. 39(3): 367-390.

Wolch JR (1995) Corporate philanthropy, urban research, and public policy. America RF, ed. Philanthropy and Economic Development (Greenwood Press, Westport, CT), 16-37.

Wooldridge JM (2002) Econometric Analysis of Cross Section and Panel Data (MIT Press, Cambridge, MA).

Wooten M, Hoffman AJ (2008) Organizational fields: Past, present and future. Greenwood R, Oliver C, Sahlin-Andersson K, Suddaby $\mathrm{R}$, eds. The Sage Handbook of Organizational Institutionalism (Sage, Los Angeles), 130-147.

Wry T, Cobb JA, Aldrich HE (2013) More than a metaphor: Assessing the historical legacy of resource dependence and its contemporary promise as a theory of environmental complexity. Acad. Management Ann. 7(1):441-488.

Zhang J, Marquis C, Qiao K (2016) Do political connections buffer firms from or bind firms to the government? A study of corporate charitable donations of Chinese firms. Organ. Sci. 27(5): $1307-1324$.

Christopher Marquis is the Samuel C. Johnson Professor in Sustainable Global Enterprise at the Johnson Graduate School of Management, Cornell University. He studies the environmental sustainability and shared value strategies of global corporations, with a particular emphasis on firms in China. He received his Ph.D. from the University of Michigan.

András Tilcsik is assistant professor of strategic management at the Rotman School of Management and a fellow at the Michael Lee-Chin Family Institute for Corporate Citizenship at the University of Toronto. His research focuses on the organizational aspects of work, employment, and occupations, and the social consequences of corporate behaviors. He received his Ph.D. from Harvard University. 